Лявщун Л. В.

доктор філологічних наук, професор філіал «Інституту мови і літератури імені Якуба Коласа і Янки Купали» Центр досліджень білоруської літератури НАН Білорусь

\title{
КАТЭГОРЫЯ КАМІЧНАГА
}

\section{Ў МАСТАЦКАЙ І КАГНІТЫЎНАЙ ПРАСТОРАХ} ЎСХОДНЕСЛАВЯСКАГА СЯРЭДНЯВЕЧЧА

\section{I НОВАГА ЧАСУ}

Автор здійснила спробу осмислити і диференціювати естетичну категорію комічного в контексті християнської онтології та антропології.

Ключові слова:комічне, онтологія, антропологія.

Автор предпринимает попытку осмыслить и дефинировать эстетическую категорию комического в контексте христианской онтологии и антропологии.

Ключевые слова: комическое, антология, антропология. 
The author attempts to comprehend and give the definition of the aesthetic category of the comic in the context of the Christian ontology and anthropology.

Keywords: comical, ontology, anthropology.

Мир есть смех Бога, и смех есть мир смеющегося. Кто смеется, возвышается до Бога, становясь миниатюрным создателем веселого творения, до истребления ничто, до противоречащего противоречию...

А. Цейзинг

Камічнае відавочна адносіцца да ліку тых «закрытых катэгорый», пра якія ў свой час трапна сказаў А. В. Міхайлаў. «Калі зайсиі ўглыб тэорыі літаратуры ва ўсласным сэнсе слова, то мы сустракаем мноства слоу, пачынаючы з якогасьиі "метаду" альбо "стылю", якія амаль закрыты... Між тым, у іх ёсчь свая гісторыя, і прыйшоў час, калі трэба вось гэту гісторыю выводзіиь на паверхню і зведавачьь» [Михайлов 2001: 213].

Традыцыйна «камічнае» узводзіцца да грэчаскага komikos вясёлы, смешны, ад komos - вясёлы гурт пераапранутых на сельскім свяце Дыёніса ў старажытнай Грэцыі, і азначаецца як такая эстэтычная катэгорыя, праз якую мастацкімі сродкамі выяўляюцца рэчы і феномены, што маюць нейкую неадпаведнасць чаканаму (эстэтычнаму ідэалу, гістарычнаму ходу падзей, прызнанаму этыкету і г. д.), унутранае алагічнае пярэчанне альбо яўную бязглудзіцу i, разам з тым, даецца ацэнка іх праз смех у той ці іншай форме.

Як першае ўяўленне (прырода камічнага), так і другое (форма яго рэалізацыя / праяўлення) падаецца небясспрэчным, бо, па-першае, далёка не ўсялякая неадпаведнасць чаканаму, не ўсялякі алагізм ці бязглудзіца спараджаюць менавіта камічнае; тым самым спараджаецца і трагічнае, і жахлівае, і ўзвышанае, і г. д; па-другое, далёка незаўсёды камічнае ацэньваецца менавіта праз смех. Дарэчы, апошняе прызнаецца шмат якімі даследчыкамі гэтай катэгорыі, якія папярэджваюць ад атаесамлення камічнага і смешнага, заўважаючы, што калі ўсё смешнае заўсёды камічна, то не усё камічнае смешна 
[Борев 2002: 85]. Аднак і гэтая апошняя заўвага падаецца нам не абсалютна дакладнай: ёсць шмат рэчаў і з'яў, якія выклікаюць смех, але, разам з тым, не адносяцца да катэгорыі камічнага - смех маці над лепетам свайго дзіця; смех дзіцяці, якое радуецца сустрэчы 3 матулей; смех над гульнёй кацяня і г.д.; а таксама, як трапна заўважыў С. С. Аверынцаў, «смех як аўтаматычная рэакиыя нерваў $і$ мускулаў, якой можна маніпуліраваџь, што $i$ робіциа публічна на любым камічным прадстайленні» [Аверинцев 1992: 9], дзе «за кампанію» смяюцца нават і над тым, што не падалося 6 смешным, каб не «смех у зале».

Ды ўвогуле, смех - не больш як суб 'ектыууная рэакцыя, якая залежыць ад тэмпераменту рэцыпіента, яго пачуцця гумару, ад эрудыцыі і, зразумела, ад сітуатыўнага кантэксту, таму смех і бывае такім розным - ад мяккага і добрага ў гумары да жорсткага i бязлітаснага ў інвектыве...

Што ж да кульутры ўсходнеславянскага сярэднявечча, то тут катэгорыя камічнага як такая ўвогуле, наколькі можна меркаваць, не даследавалася; а на матэрыяле артэфактаў ранняга новага часу навуковыя памкненні даследчыкаў засяроджваліся выключна на праблеме смеха і смешнага ў межах так званай «дэмакратычнай сатыры» пры стварэнні ёй культурных маргінальных па сваім характары [Сайнаков 2001] «антысветаў» розных кшталтаў і «антыпаводзін» у іх (гл. даследаванні Д. С. Ліхачова, А. М. Панчанкі, Ю.М.Лотмана, Б. Успенскага і інш.). Прычым вывучэнне адбывалася без дакладнага вызначэння зместу, складу і межаў самога паняцця «смех», а таму, зразумела, і без распрацоўкі тыпалогіі і класіфікацыі смешнага.

Такое стаўленне да праблемы тлумачыцца, хутчэй за ўсё, папершае, ужо згаданым атаесамленнем камічнага і смешнага; падругое, апрыёрна прынятым на веру перакананнем (дарэчы, заходнехрысціянскага паходжання), што, маўляў, «Хрыстос ніколі не смяяўся» і таму хрысціянская культура быццам ба цалкам адмоўна ставілася да смеху, так што шукаць і даследаваць у ёй камічнае немагчыма. Не выратоўваюць становішча нават і вельмі трапныя 
заўвагі-ўдакладненні С. С. Аверынцава, які разважаў наконт Бахцінскай канцэпцыі «вызвалення праз смех». Сяргей Сяргеевіч, у прыватнасці, указаў - што ўжо згадвалася вышэй - на наяўнасць феномену «міжвольнага» смеху, г. зн. часова адмяняючага дзеянне асабістай волі чалавека, што прымушае прызнаць: не кожны акт смеху з'яўляецца вызваленнем ад чагосьці, бо калі асабістая воля не дзейнічае, смех ператвараецца з акта ў пасіўны псіхалагічны стан (не тое, што я раблю, а тое, што са мной робіцца) [Аверинцев 1992: 9]. Такім чынам, заўважае даследчык, пераход ад несвабоды да свабоды ўносіць момант некаторай новай несвабоды [тамсама], што не адпавядае хрысціянскаму вучэнню (гнасеалогіi, антрапалогіi, сатэрыялогіi), сутнаць якога выражана ў словах Хрыста: «пазнаеце Ісціну, і Ісціна зробіць вас свабоднымі» (Ін. 8: 32).

C. С. Аверныцаў таксама адзначыў, што, паколькі смех, згодна 3 канцэпцыяй М. М. Бахціна, ёсць пераход ад некаторай несвабоды да некаторай свабоды, то цяжка чакаць, каб Хрыстос - адзіная ў сусвеце абсалютна свабодная істота - мог бы над чым-небудзь смяяца-вызваляцца, паколькі «у пункце абсалютнай свабоды смех немагчымы, бо залішні» [Аверинцев 1992: 8]. Падобна да таго давядзем да лагічнай высновы думку даследчыка - і мастакі хрысціянскай культуры (зноў-такі, згодна 3 царкоўнымі правіламі, святыя айцы) не маюць падставаў для смеху, бо, адпаведна з ужо згаданымі словамі Самога Хрыста (Ін. 8: 32), яны таксама праз веданне Ісціны вольныя ад усяго таго, ад чаго несвабодны чалавек вызваляецца праз смех.

Аднак тут, як нідзе выразна, накрэсліваецца цяперашняя тэарэтычная «недастатковаць» у вызначэнні стасункаў паміж смешным і камічным, бо калі Хрыстос і не смяяўся, то напэўна ж раз-пораз усміхаўся, згадваючы камічныя сітуацыя, ці трапляючы у іх Сам. Напрыклад, хіба не камічным выглядае намаганне праціснуць вярблюда ў самыя вузкія варотцы Іерусаліма, якія таму і назвалі «вушамі голкі». Хіба не камічным выглядае Закхей, «старшыня над мытарамі $і$ чалавек багаты» (Лк. 19: 2), г. зн. маючы 
высокае палажэнне ў сацыяльная іерархіі, які з-за малога росту забраўся на дрэва, каб убачыць Хрыста. Хіба не камічнае непаразуменне Самаранкі: Хрыстос у адказ на яе здзіўленне, што іудзей звярнуўся з просьбай да «нячыстай», адказаў ёй: «Каб ты ведала дар Божы і Хто кажа табе: дай мне піџь, то сама прасіла б у Яго, і Ён даў бы табе ваду жывую» (Ін. 4: 10), а яна здзівілася яшчэ больш: «Табе $і$ пачарпнуць няма чым, а калодзеж глыбокі, адкуль жа у Цябе вада жывая?» I інш.

Але ўсе гэтыя камічныя - прычым, відавочна тыпова камічныя, ледзь не фарсавыя! - сітуацыі, аднак, не выклікаюць «вызваляючага смеху» ні ў Хрыста, ні ў чытачоў Евангелля. I калі Хрыстос як цалкам свабодны не мае патрэбы, па думцы Аверынцава, вызваляцца ад нечага праз смех, то наконт Яго атачэння, нават апосталаў-евангелістаў, а тым больш - пазнейшых чытачоў Евангелля гэтага сказаць нельга. Аднак і яны не смяюцца, а толькі раз-пораз ўсміхаюцца.

Скажу больш: гэтая - насамрэч уяўная - «сур'ёзнасць» тычыцца не толькі стваральнікаў і чытачоў Евангелля, не толькі сярэднявечнага хрысціянства, але ўсёй хрысціянскай культуры, у якой камічныя сітуацыі па некай невядомай нам пакуль заканамернасці ніколі не выклікаюць «вызваляючага смеху», а толькі добрую ўсмешку-адкрыццё - эфект цалкам адваротны чаканаму: не вызваленне, а набыццё; не адмаўленне, а ўзбагачэнне.

Напрыклад, у Сінайскім патэрыку (Ліманар, альбо «Луг духоўны» добраснага Іаана Мосха) у аповедзе пра Герасіма і яго льва распавядаецца, як старац, калі леў не ўвартаваў яго асла, прымусіў самога льва выконваць асліную работу - насіць ваду ў манастыр. Уявіце «цара звяроў», наўючанага як асла - ці не камічна? ці не смешна? Аднак ні Mосх, ні яго чытачы не смяюцца, а замілоўваюцца ўміраным падпарадкаваннем драпежнага звера найпадобнаму старцу...

У «Жыціі найп. Феадосія Пячэрскага» згадваецца, што ў яго маці голас быў мужчынскі, і калі хто чуў яе, але не бачыў, то думаў, 
што гаворыць мужчына. Камічна? Так. Смешна? Нам, сёнешнім, так. Але даўнія аўтар і чытач не смяюцца, хіба што ўсміхаюцца і дзівяцца ўпартасці юнака, які сумеў супроцьстаяць мужападобнай маці...

У Кіева-Пячэрскім патэрыку, у «Слове пра Грыгорыя цудатворцу», апісваецца шмат не менш камічных сітуацый. Напрыклад, такая: злодзеі прыйшлі да келлі Грыгорыя і сталі сцерагчы, калі той пойдзе да ютрані, каб абакрасці яго; Грыгорый пачуў іх прыход, бо не спаў, правёўшы ў малітвах усю ноч; памаліўся ён і аб злодзеях: «Боже, дай же сонъ рабом твоимъ, яко утрудишася всуе, врагу угажающе» (трэба ацаніць пачуццё гумару ў старца!) i па той малітве злодзеі праспалі аж 5 дзён, пакуль сам Грыгорый іх не разбудзіў, але яны за гэты час так аслабелі, што не маглі ісці, так што найпадобнаму прыйшлося іх яшчэ і накарміць, каб у іх хапіла сіл дабрацца дамоў...

У «Слове пра найпадобных святых айцах Фёдары ды Васіліі» распавядаецца, як найп. Фёдар прымусіў бесаў насіць бярвенні для пабудовы царквы...

Можна прывесці яшчэ безліч прыкладаў, якія сведчаць пра тое, што залішняй сур'ёзнасцю ў хрысціянстве вылучаюцца хіба што ханжы альбо людзе асаблівага - «сур'ёзнага» - кшалту.

У рэшще рэшт, хіба само па сабе ўцелаўленне Бога не камічная сітуацыя? Хіба гэта не лукавая насмешка Бога над д'яблам? (Выратавальная для чалавецтва насмешка, за якую Логас заплаціў пакутамі і крывёй!) Хіба гэта - не падстава для радаснага смеха чалавекаў, якія раптам усвядомілі, што Той, каго не могуць умясціць нябёсы, памясціўся ў быдлячых яслях; Таго, Хто спавіты бясконцай славай, спавілі цяпер пялюшкамі і г.д. Хіба гэта - не фарс? хіба не самае таленавітае ў гісторыі камічнага qui pro quo?!

Пытанне ў другім: калі ў сярэднявечным (як і ў сучасным) хрысціянстве з гумарам усё добра, чаму ж яно падаецца даследчыкам гэткай «несмяянай»; а потым 3 гэтай зацятай сур'ёзнасці раптам выпраменьвае - гэткім deus ex machine - демакратычная сатыра новага часу; а ўжо для ўнутранай скразной іроніі «Слова 
пра паход Ігара» альбо «Паслання да празвітара Фамы» Клімента Смаляціча ці «Малення / Слова Данііла Заточніка» увогуле не знаходзіцца тлумачэнняў і належнага месца ані ў гісторыі даўняга пісьменства, ані ў структуры паэтыкі. Ствараецца ўражанне, што камічнае ў хрысціянскай культуры не проста іншае, чым у секулярнай, але, перафразуючы таго ж С. С. Аверынцава, «у іншым сэнсе» камічнае.

Мяркуем, што зварот менавіта да хрысціянскага мастацкага канону можа даць даследчыкам цвёрдыя падставы як для тэарытычнай распрацоўкі катэгорыі камічнага, так і для высвятлення яе стасункаў з феноменам смешнага і яго разнавіднасцямі, прычым не толькі ў сярэднявечнай культуры, але і ў мастацтве новага часу.

Каб выявіць спецыфіку стварэння камічнага мастацкага вобразу, трэба нагадаць увогуле алгарытм вобразатворчасці паводле мастацкага канону хрысціянскай культуры.

Вобраз у хрысціянскім мастацтве выконвае роль структурнага прынцыпу, які гарантуе цэласнасць усёй сістэмы. У прыватнасці, адпаведна меркаванню Клімента Александрыйскага, пачынальніка распрацоўкі тэалогіі вобраза ў хрысціянскай культуры, Бог у гэтай сістэме - зыходны пункт вобразнай іерархіі і Архетып усіх наступных выяў. Логас - першы, максімальна ізаморфны Яму, вобраз Архетыпу, невідочны і пачуццёва неўспрымальны. Вобраз Логаса - духоўная сутнасць чалавека. Нарэшще, чацверты вобраз Архетыпу - мастацкія выявы, створаныя чалавекам, якія пэўным чынам залежаць ад модусу быцця мастака (г.зн. праяўленасці яго духоўнай сутнасці - падабенства Божага) і яго мэтаў [Левшун 2009: 156-165]. Такім чынам, любая мастацкая выява паводле канону хрысціянскай культуры мысліцца як, перш за ўсё, вобраз свайго першавобразу, альбо архетыпу (які, у сваю чаргу, з'яўляецца вобразам першаснага Архетыпу - Самога Творцы); і ва ўсім прыпадабняецца першавобразу, адрозніваючыся ад яго толькі прыродай. Такім чынам, мастацкі вобраз, з аднаго боку, не можа атаесамляцца $з$ выяўленым; а $з$ другога боку, ён не можа выяўляць тое, 
што не створана Богам, што не мае на сабе пячаткі Божага стварэння [Левшун 2009: 126-139].

Падсумоўваючы, можна сказаць і так: любы мастацкі вобраз, паводле канону хрысціянскай культуры, ёсць выява Божага стварэння, «думкі Бога» пра тую ці іншую рэч / з'яву, а, значыць, у рэшще рэшт, - выява Самога Творцы сусвету. Зразумела таксама, што мастацкі вобраз ніяк не можа быць адэкватным выражэннем «думкі

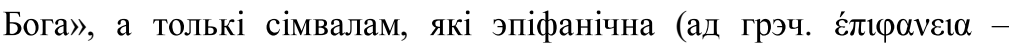
паказваю, выяўляю) далучае рэцыпіента да яе. Зыходзячы з такой канцэпцыі мастацкага вобраза, прыніжэнне і асмяянне стварэння мысліцца ў хрысціянскай культуры - прычым зусім не метафарычна, а наўпрост! - прыніжэннем і асмяяннем Творцы. Гэта часткова тлумачыць «сур' езнасць» хрысціянскіх мастацкіх вобразаў.

Але як быць са згаданымі вышэй - і вельмі не рэдкімі! прыкладамі бясспрэчна камічнага ў хрысціянстве? Які ж, у такім выпадку, механізм узнікнення камічнага ў хрысціянскай мастацкай свядомасці і культуры? I ў чым тут сутнасць гэтай з'явы і катэгорыі?

Перадусім, зразумела, што камічнае ў хрысціянстве мае не caџыяльны, як у секулярнай мастацкай свядомасці новага часу, $a$ анталагічны характар, хоць ў аснове камічнага ў хрысціянскай культуры ляжыць, па вялікім рахунку, тое ж qui pro quo, што і ў секулярнай. Як ні парадаксальна, у хрысціянскай свядомасці яно вонкава вельмі блізкае да таго самага дыянісійскага komos (гурта пераапранутых), але «пераапранутасць» тут, як бачыцца, асаблівага роду: не «нізкае» апранаецца тут у строі «высокага» (як звычайна азначаюць сутнасць камічнага ў секулярнай культуры), а, наадварот, «высокае» уціхамірваецца да «нізкага» - Царства Божае саступае на зямлю «в рабьем зраке» (Філ. 2: 6-7) ў выглядзе раба, юрода. Яно і далучаныя да Яго не стасуюцца з чалавечымі ўзаконеннямі і ўяўленнямі; Яно «для іюдзеяў спакуса, а для элінаў вар'яитва» (1Кар. 1: 23). Таму Яго прадстаўнікі, пачынаючы з Самога Хрыста і да апошняга святога юрода, якія ўспрымаюцца светам «чувственныма очима», як выразіўся св. Варлаам у «Аповесці пра 
мудрага цара», выглядаюць калі не вар'ятамі, то праставатымі небаракамі і выклікаюць да сябе паблажлівую літасць. У гэтай паблажлівай літасці, якую зямное адчувае да нябеснага, часовае - да неўміручага, грэшнае - да святасці і змяшчаецца далікатная, выратавальная камічнасць (для тых, хто разумее!) кананічнага хрысціянскага мастацтва. Менавіта праз камічнае самапрыніжэнне ўваходзіць Царства Божае у наш свет, бо без гэтага кеназісу Яму проста не ўціснуцца ў «гольныя вушы» нашай грахоўнасці. Нездарма ж Хрыстос вучыў сваіх апосталаў: «хто хоча між вас быџь большым, хай будзе вам слугою» (Мф. 20: 26 і парал.) - зноў-такі тыпова фарсавая сітуацыя: гаспадар прыслужвае свайму слузе. Смех у дадзенай сітуацыі выражае не ацэнку, не катарсіс, не вызваленне, а чыстую радасць узнавання, прычынення і суцяшэння: вось Яно, Божае Царства, насамрэч сярод нас, «унутры нас» (Лк. 17: 21)!

Такім чынам, прычына таго, што ў хрысціянскім сярэднявеччы даследчыкі не бачуць камічнага, палягае зусім не ў «сур'ёзнасці хрысціянства», а ў тым, што катэгорыя камічнага ў хрысціянскай культуры мае адметную структуру, і таму строгі этыкет свету прымае анталагічны камізм хрысціянскай свядомасці за вар'яцтва альбо замах на «асновы быцця» (хоць, па праўдзе сказаць, так яно і ёсць), што, вядома ж, у свядомасці пэўнага кшталту не можа ўспрымацца ні як камічнае, ні як смешнае. Уяўленне ж пра тое, што Хрыстос ніколі не смяяўся можна, такім чынам, лічыць своеасаблівым водападзелам паміж хрысціянскай свядомасцю і секулярнай, паміж культурай рэлігійнай і гуманістычнай, нават калі апошняя сама сябе будзе шчыра далучаць да рэлігійнай, бо ў гэтым выпадку пад маскай «сур'ёзнага хрысціянства» насамрэч хаваецца, хутчэй за ўсё, ваяўнічы гуманізм...

\section{БІБЛІЯГРАФІЯ}

Аверинцев 1992 - Аверинцев С. С. Бахтин, смех, христианская культура /

С. С. Аверинцев // М. М. Бахтин как философ. - М. : Наука, 1992, - С. 7-19. Борев 2002 - Борев Ю. Б. Эстетика : учебник / Ю. Б. Борев. - М. : Высш. шк., 2002. - $511 \mathrm{c}$.

Левшун 2009 - Левшун Л. В. Введение в теоретическую поэтику восточнославянской средневековой книжности / Л. В. Левшун. - Минск : Бел. навука, 2009. - 451 с. 
Михайлов 2001 - Михайлов А. В. Несколько тезисов о теории литературы. Стенограмма доклада, сделанного 20 января 1993 года на заседании Научного совета ОЛЯ РАН «Теория и методология литературоведения и искусствознания» / А. В. Михайлов // Литературоведение как проблема. Труды Научного совета «Наука о литературе в контексте наук о культуре». - М. : Наследие, 2001. - С. 201-279.

Сайнаков 2001 - Сайнаков Н. А. Общекультурологическая концепция смеха и исторический анализ маргинальности (по материалам медиевистики) / Н. А. Сайнаков // Методологические и историографические вопросы исторической науки : сб. статей / отв. ред. Б. Г. Могильницкий. - Томск : Изд-во Томского унта, 2001. - Вып. 26. - С. 101-112 (192 с.). 